\title{
Root Herbivores Drive Changes to Plant Primary Chemistry, but Root Loss Is Mitigated under Elevated Atmospheric $\mathrm{CO}_{2}$
}

\author{
Scott W. McKenzie ${ }^{1,2,3,4}$, Scott N. Johnson ${ }^{5}$, T. Hefin Jones ${ }^{4}$, Nick J. Ostle ${ }^{6}$, \\ Rosemary S. Hails ${ }^{3}$ and Adam J. Vanbergen ${ }^{1 *}$
}

${ }^{1}$ Centre for Ecology and Hydrology, Edinburgh, UK, ${ }^{2}$ The James Hutton Institute, Dundee, UK, ${ }^{3}$ Centre for Ecology and Hydrology, Wallingford, UK, ${ }^{4}$ School of Biosciences, Cardiff University, Cardiff, UK, ${ }^{5}$ Hawkesbury Institute for the Environment, University of Western Sydney, Sydney, NSW, Australia, " ${ }^{6}$ Lancaster Environment Centre, Lancaster University, Lancaster, UK

Above- and belowground herbivory represents a major challenge to crop productivity and sustainable agriculture worldwide. How this threat from multiple herbivore pests will change under anthropogenic climate change, via altered trophic interactions and plant response traits, is key to understanding future crop resistance to herbivory. In this study, we hypothesized that atmospheric carbon enrichment would increase the amount (biomass) and quality (C:N ratio) of crop plant resources for above- and belowground herbivore species. In a controlled environment facility, we conducted a microcosm

OPEN ACCESS

Edited by:

Susana M. P. Carvalho, University of Porto, Portugal

Reviewed by: Zhilong Bao,

University of Florida, USA

Piotr Trebicki,

Agriculture Victoria, Australia

*Correspondence:

Adam J. Vanbergen

ajv@ceh.ac.uk

Specialty section:

This article was submitted to Crop Science and Horticulture, a section of the journal Frontiers in Plant Science

Received: 12 February 2016 Accepted: 27 May 2016

Published: 14 June 2016

Citation:

McKenzie SW, Johnson SN, Jones TH, Ostle NJ, Hails RS and Vanbergen AJ (2016) Root Herbivores Drive Changes to Plant Primary Chemistry, but Root Loss is Mitigated under Elevated Atmospheric $\mathrm{CO}_{2}$. Front. Plant Sci. 7:837. doi: 10.3389/fpls.2016.00837 experiment using the large raspberry aphid (Amphorophora idaei), the root feeding larvae of the vine weevil (Otiorhynchus sulcatus), and the raspberry (Rubus idaeus) host-plant. There were four herbivore treatments (control, aphid only, weevil only and a combination of both herbivores) and an ambient $\left(\mathrm{aCO}_{2}\right)$ or elevated $\left(\mathrm{eCO}_{2}\right) \mathrm{CO}_{2}$ treatment (390 versus $650 \pm 50 \mu \mathrm{mol} / \mathrm{mol}$ ) assigned to two raspberry cultivars (cv Glen Ample or Glen Clova) varying in resistance to aphid herbivory. Contrary to our predictions, $\mathrm{eCO}_{2}$ did not increase crop biomass or the $\mathrm{C}: \mathrm{N}$ ratio of the plant tissues, nor affect herbivore abundance either directly or via the host-plant. Root herbivory reduced belowground crop biomass under $\mathrm{aCO}_{2}$ but not $\mathrm{eCO}_{2}$, suggesting that crops could tolerate attack in a $\mathrm{CO}_{2}$ enriched environment. Root herbivory also increased the C: $\mathrm{N}$ ratio in leaf tissue at $\mathrm{eCO}_{2}$, potentially due to decreased $\mathrm{N}$ uptake indicated by lower $\mathrm{N}$ concentrations found in the roots. Root herbivory greatly increased root $\mathrm{C}$ concentrations under both $\mathrm{CO}_{2}$ treatments. Our findings confirm that responses of crop biomass and biochemistry to climate change need examining within the context of herbivory, as biotic interactions appear as important as direct effects of $\mathrm{eCO}_{2}$ on crop productivity.

Keywords: aphid, vine weevil, carbon, nitrogen, plant productivity, aboveground, belowground

\section{INTRODUCTION}

Root herbivory is very damaging to plants, especially when combined with multiple biotic and abiotic stresses (Zvereva and Kozlov, 2012) that can lead to substantial losses of crop yields (Villani and Wright, 1990; Blossey and Hunt-Joshi, 2003; Blackshaw and Kerry, 2008). Crop traits such as compensatory growth are key to crop survival and primary productivity in the face of herbivore 
pest pressure (Strauss and Agrawal, 1999; Watts et al., 2011; Huang et al., 2012; Robert et al., 2014). Plants, however, generally are less able to compensate for root herbivory compared to shoot herbivory (Johnson et al., 2016a). Moreover, even in simple agroecosystems insect herbivores occur as part of an above-belowground community (Megías and Müller, 2010; Soler et al., 2012). Consequently, the direct and indirect (mediated by host-plant plasticity) interactions among plants and herbivores occupying different guilds or niches, are key to understanding crop resistance and resilience to herbivory (Johnson et al., 2009; Huang et al., 2013; McKenzie et al., 2013; Hagenbucher et al., 2014).

Environmental stressors such as drought, elevated atmospheric $\mathrm{CO}_{2}\left(\mathrm{eCO}_{2}\right)$ and temperature can modify these trophic interactions (Johnson et al., 2011b; Stevnbak et al., 2012; Ryalls et al., 2013; Johnson et al., 2016a,b). Atmospheric $\mathrm{CO}_{2}$ concentrations are predicted to continue increasing during the 21st century and this is likely to affect plant productivity directly (Ainsworth and Long, 2005; Leakey et al., 2009; IPCC, 2013). For instance, greater accrual of plant biomass or altered biochemistry is one outcome of $\mathrm{eCO}_{2}$ (e.g., Hentley et al., 2014; Dáder et al., 2016). However, such effects may vary greatly due to intrinsic differences between plant species or the presence of other environmental stressors such as water stress or herbivory (Ainsworth and Long, 2005; Bader et al., 2009; Kohler et al., 2009; Johnson et al., 2011a; Johnson and Riegler, 2013). Changes to plant productivity has the potential to affect the performance of herbivores via changes in the quality (e.g., altered $\mathrm{C}$ and $\mathrm{N}$ content) of their plant food resource (DeLucia et al., 2012; Robinson et al., 2012). For example, in an $\mathrm{eCO}_{2}$ environment concentrations of $\mathrm{N}$ typically decrease by $17 \%$ in leaves and by $7 \%$ in roots (Robinson et al., 2012). This results in higher C: $\mathrm{N}$ ratios in plant tissues which generally reduces host plant quality for herbivores (Luo et al., 2006; Dáder et al., 2016), but this is a far from universal response. Many insect taxa respond idiosyncratically depending on species (e.g., aphids: Bezemer et al., 1999; Newman et al., 2003; Sun and Ge, 2011; Dáder et al., 2016; Ryalls and Harrington, 2016; Trębicki et al., 2016) or empirical information is so scarce for other groups (e.g., Staley and Johnson, 2008) that we cannot generalize either way. Moreover, while plant biomass or nutrient levels may alter in an $\mathrm{eCO}_{2}$ environment this may be moderated by the effects of herbivory. For instance, Johnson and Riegler (2013) showed concomitant increases in root herbivory in Eucalyptus seedlings, reversed several of the effects of elevated $\mathrm{CO}_{2}$ on plant growth and chemistry.

Herbivores shape plant primary productivity either by manipulating chemistry directly (e.g., aphid induced changes in source-sink relations; Crawley, 1989) or causing the plant to mobilize resources away from sites of attack (e.g., induced resource sequestration; Orians et al., 2011). Induced resource sequestration is thought to be a tolerance strategy to relocate resources temporarily away from the attacker (Kaplan et al., 2008; Schultz et al., 2013). This has traditionally focussed on plant attack aboveground, with photoassimilate transported to the roots for storage following shoot herbivory. Whether plants translocate primary compounds in the reverse direction in response to root herbivory has been subject to recent debate (Johnson et al., 2016a,b). Evidence is limited, but Robert et al. (2014) showed that maize plants infested with root herbivores allocated carbon to the stems as a prelude to root regrowth. Similarly, nitrogen reallocated from roots to shoots in knapweed (Newingham et al., 2007) and the stems in milkweed (Tao and Hunter, 2013) following root attack. It has been suggested, however, that root herbivores may manipulate their hosts to allocate primary metabolites belowground to improve host plant quality (Erb et al., 2013). Indeed, there is evidence that root herbivory causes increases in root carbon (Pierre et al., 2012; Robert et al., 2014) and blackcurrant (Ribes nigrum) plants attacked by root-feeding vine weevils had $72 \%$ lower concentrations of foliar phosphorus, with a concomitant increase of 56\% in the roots (Johnson et al., 2013). In the present study, we term this 'feeding-induced resource accumulation.'

It is clear that herbivores have the capacity to moderate plant primary chemistry and these impacts may vary at different $\mathrm{CO}_{2}$ concentrations. In this study we investigate how $\mathrm{eCO}_{2}$ influences plant (red raspberry Rubus idaeus L.) growth and primary chemistry when under attack from an aboveground (large raspberry aphid - Amphorophora idaei Börner) and belowground (vine weevil larvae - Otiorhynchus sulcatus F.) herbivore. Moreover, these two herbivores are thought to influence one another positively when sharing a host plant (McKenzie et al., 2013). In this study, we hypothesized that atmospheric carbon enrichment would alter the amount and quality of resources for herbivore species thus altering crop susceptibility to herbivory. Specifically we predicted that:

(i) $\mathrm{eCO}_{2}$ would cause an increase in plant biomass and the C:N ratio of above and belowground plant tissues,

(ii) the $\mathrm{CO}_{2}$ driven increase in host-plant biomass would result in greater herbivore abundance, above and belowground, but this may be negated by high C:N reducing host-plant quality

(iii) root herbivory will impede crop biomass gains under $\mathrm{eCO}_{2}$ and alter plant primary chemistry, via one or more mechanisms including impaired uptake of $\mathrm{N}$, induced resource sequestration or feeding-induced resource accumulation.

\section{MATERIALS AND METHODS}

\section{Experimental Design}

A microcosm experiment was carried out with 192 individual raspberry plants challenged with multifactorial combinations of herbivore, cultivar, and $\mathrm{CO}_{2}$ treatments. The experiment was performed in three runs (64 plants $\times 3$ occasions) to avoid pseudoreplication and with $\mathrm{CO}_{2}$ treatments switched between different chambers per run to avoid any potential influence of chamber identity on the experiment. Each experimental run was of 10-weeks duration so the whole experiment spanned in total the period November 2011 - November 2012. Two cultivars (Glen Ample or Glen Clova), which varied in resistance to insect 
herbivory (Glen Clova was selectively bred for resistance to aphid herbivory), were exposed to an herbivore treatment comprising four levels: (i) herbivore-free control, (ii) aphid only, (iii) weevil only, and (iv) both herbivores present (12 plant replicates each). These herbivore $\times$ cultivar combinations were further challenged by exposure to either ambient $(390 \pm 50 \mu \mathrm{mol} / \mathrm{mol})$ or elevated $(650 \pm 50 \mu \mathrm{mol} / \mathrm{mol})$ atmospheric $\mathrm{CO}_{2}$ concentrations $(n=96)$, with the latter based on Climate Change (2007) predictions of atmospheric $\mathrm{CO}_{2}$ concentrations by 2100. Individual plant replicates were assigned to randomized blocks within four controlled environment chambers $(\sim 4 \mathrm{~m} \times 9 \mathrm{~m})$ of the GroDome $^{\mathrm{TM}}$ climate change research facility at the Centre for Ecology and Hydrology (CEH), Wallingford, UK. A $\mathrm{CO}_{2}$ sensor (GMW22; Vaisala, Finland) in every chamber and was connected to a controller unit (AL2-24MR-D micro-controller, Mitsubishi, Japan). If $\mathrm{CO}_{2}$ levels fell below the treatment level (390 and $650 \mu \mathrm{mol} / \mathrm{mol}$, respectively), $\mathrm{CO}_{2}$ gas (BOC, UK) was injected for $1 \mathrm{~s}$, followed by a $30 \mathrm{~s}$ delay, repeating until the required atmospheric concentration was reached.

Individual plants were grown for 10 -weeks from rootstock in the $\mathrm{CO}_{2}$ treatment chambers to which they were assigned. Photoperiod was maintained at 16:8 h (light:dark) with additional lighting provided by halide bulbs $(400 \mathrm{~W})$ when photosynthetic active radiation (PAR) dropped below $400 \mu \mathrm{mol} / \mathrm{s} / \mathrm{m}^{2}$, and a controlled daytime temperature of $18^{\circ} \mathrm{C}\left( \pm 2^{\circ} \mathrm{C}\right)$ and minimum night temperature of $10^{\circ} \mathrm{C}\left( \pm 2^{\circ} \mathrm{C}\right)$. Weevil eggs collected from cultures maintained at $18^{\circ} \mathrm{C}$ were added (20 per replicate) to the soil of appropriate replicates (weevil only and both herbivore treatment) in Week 4, with egg hatch occurring some 2 weeks later (Son and Lewis, 2005). Three adult large raspberry aphids were added to the upper-most unfurled leaf of the appropriate plants (aphid only and both herbivore treatment) in Week 8 . The chronological sequence of weevil and aphid colonization of host-plants simulated in this experiment mimics the natural phenology of these organisms observed in the field (Moorhouse et al., 1992; McMenemy et al., 2009).

\section{Plant and Insect Sampling}

After 10 weeks, aphid population sizes were determined by counts and removal of individuals. Vine weevil larvae were extracted from the soil for $24 \mathrm{~h}$ with Tullgren funnels and counted. Plants were carefully removed from the soil, roots washed and a random sample of leaves and roots was taken and snap-frozen in liquid nitrogen for analysis of plant primary chemistry. The remainder of the aboveground (stems, leaves) and belowground (root) plant biomass was then oven-dried $\left(80^{\circ} \mathrm{C}\right.$ for $\left.24 \mathrm{~h}\right)$ and weighed $(\mathrm{g})$. After being snap-frozen the roots and shoot samples were freeze dried for $24 \mathrm{~h}$, then the tissue samples $(\leq 5 \mathrm{mg}$ ) were ball-milled to a fine powder for subsequent C:N analysis. Chemical analysis of carbon and nitrogen concentrations of leaf and root tissue was undertaken at the Centre for Ecology and Hydrology (Lancaster), using an Exeter Analytical Elemental Analyser (EAI, Coventry, UK).

\section{Statistical Analysis}

Co-linearity amongst parameters of plant biomass and biochemistry was initially assessed testes with Pearson correlation coefficients (proc CORR in SAS version 9.3). Subsequently, the response of plant biometrics (above- and belowground biochemistry and biomass) and herbivore abundance (aphid and weevil counts) to experimental treatments were analyzed with generalized linear mixed effects models (proc GLIMMIX). Categorical experimental treatments were: 'herbivore' (herbivore-free control, aphid only, weevil only, both herbivores), 'Cultivar' (Glen Ample or Glen Clova) and ' $\mathrm{CO}_{2}$ regime' $\left(\mathrm{aCO}_{2}\right.$ or $\left.\mathrm{eCO}_{2}\right)$. For models of insect herbivore abundance, 'herbivore treatment' was replaced by continuous predictors: above- or belowground plant dry weight, $\%$ concentration of $\mathrm{C}, \mathrm{N}$, or C:N ratio of leaves or roots. Plant responses were modeled with Gaussian distribution and an identity link function, plant biomass was log transformed to meet the assumption that residuals were normally distributed with homogeneity of variance. Aphid and weevil counts were modeled with a Poisson distribution and a log link function.

Random effects were fitted to all models to account for different chambers used during the three experimental runs (chamber nested within run) and the randomized block design (block). Over-dispersion of count data in herbivore abundance models was accounted for with an observation-level parameter 'plant replicate' fitted as an additional random effect (Elston et al., 2001). The full model (experimental treatments and their pairwise interactions) was simplified through backward stepwise elimination of the least significant term (interactions before main effects) until a minimum adequate model was obtained. $F$-ratios and $p$-values reported are adjusted (SAS type III) for the other significant parameters retained in the final reduced model. Statistical significance of main effects are always reported, whereas two-way interactions are reported only where $P<0.05$. Degrees of freedom were estimated using the Satterthwaite approximation (Littell et al., 1996). Least square means (with Bonferroni adjusted $p$-values) were plotted to show the effect of the significant explanatory variables conditional on other effects in the final models.

\section{RESULTS}

\section{Crop Biomass}

Above- and belowground biomass were positively correlated (0.67; $p<0$. 0001). In contrast to our prediction, $\mathrm{eCO}_{2}$ concentrations did not increase crop biomass overall, either aboveground $\left(F_{1,4}=1.78, p=0.2544\right)$ or belowground $\left(F_{1,4}=3.54, p=0.1345\right)$. There was, however, an interaction between $\mathrm{CO}_{2}$ treatment and crop cultivar $\left(F_{1,175}=4.52\right.$, $p=0.0349$ ), explained by $c v$. Glen Ample accruing greater aboveground biomass than $\mathrm{cv}$. Glen Clova at $\mathrm{eCO}_{2}$ levels (Bonferroni adjusted $p=0.0252$ ).

Although there was no indication of any effect of herbivore treatment on aboveground biomass $\left(F_{3,173}=0.44 p=0.7275\right)$, root herbivory consistently reduced root biomass with treatments where weevil larvae were present (weevil only, both herbivore species) yielding significantly less root biomass than treatments without weevils (control and aphid only; $F_{3,172}=5.88$, 
$p=0.0008$, Figure 1). Root biomass was also affected by the significant interaction between the herbivore and $\mathrm{CO}_{2}$ treatments $\left(F_{3,172}=4.66, p=0.0037\right.$, Figure 1). While under $\mathrm{aCO}_{2}$ conditions root biomass was significantly reduced by treatments including root-feeding weevils (weevils only and both herbivore species), this effect dissipated under $\mathrm{eCO}_{2}$ (Figure 1), suggesting a mitigation of herbivory on roots.

The identity of the crop cultivar also had an influence on above- and belowground crop biomass. Aboveground biomass was greatest in the cultivar (Glen Clova) selectively bred to be most resistant to aphid herbivory (Glen Clova LS mean $=-0.32 \pm 0.17$; Glen Ample LS mean $=-0.19 \pm 0.17$; $\left.F_{1,175}=3.93, p=0.0349\right)$. Whereas, belowground biomass was significantly greater in the cultivar (Glen Ample) that was less resistant to aphid herbivory (Glen Clova LS mean $=-0.03 \pm 0.16$; Glen Ample LS mean $=-0.23 \pm 0.16$; $\left.F_{1,171}=4.17, p=0.0427\right)$.

\section{Crop Biochemistry}

Correlation analysis revealed the intimately connected balance of $\mathrm{C}$ and $\mathrm{N}$ within the crop plant and these relationships are shown in Supplementary Material (Appendix S1).

As with aboveground crop biomass, and contrary to prediction, the experimental $\mathrm{eCO}_{2}$ treatment had little overall impact on plant tissue biochemistry. There was only a slight increase in percent leaf C (LS mean: ambient $=42.27$, elevated $\left.=42.98 \pm 0.1658 ; F_{1,4}=9.24, p=0.0388\right)$, with little overall effect on leaf $\mathrm{N}\left(F_{1,4}=6.26, p=0.0672\right)$ and hence the $\mathrm{C}: \mathrm{N}$ ratio of leaves $\left(F_{1,4}=6.47, p=0.0666\right)$. The $\mathrm{CO}_{2}$ treatment had no effect on the percent $\mathrm{C}\left(F_{1,4}=0.00, p=0.9968\right)$, percent $\mathrm{N}\left(F_{1,4}=0.50, p=0.5207\right)$ or the C:N ratio $\left(F_{1,4}=0.59\right.$, $p=0.4909)$ of roots.

There was no evidence that the herbivore treatment affected the overall percent content of $\mathrm{C}\left(F_{3,177}=0.98, p=0.4019\right)$ or $\mathrm{N}\left(F_{3,174}=1.82, p=0.1452\right)$ or the $\mathrm{C}: \mathrm{N}$ ratio $\left(F_{3,169}=2.00\right.$, $p=0.1158$, Figure 3 ) of leaf tissues. While root herbivory did not significantly affect belowground $\mathrm{N}$ content $\left(F_{3,174}=2.24\right.$, $p=0.0851)$, it did greatly increase the $\mathrm{C}$ content of root tissues relative to control and aphid treatments $\left(F_{3,171}=30.99\right.$, $p<0.0001$, Figure 2). This herbivore effect was reflected in a higher C:N ratio $\left(F_{3,174}=4.68, p=0.0036\right)$ in roots where belowground herbivory was present, relative to the aphid-only herbivore treatment (Figure 3).

Furthermore, similar to the effect of root herbivory on belowground biomass (see above), the interaction between the herbivore and $\mathrm{CO}_{2}$ treatments affected percentage $\mathrm{N}$ $\left(F_{3,174}=4.02, p=0.0085\right)$ and $\mathrm{C}: \mathrm{N}$ ratio $\left(F_{3,169}=3.01\right.$, $p=0.0319)$ of leaves. At $\mathrm{aCO}_{2}$ conditions, the leaf $\mathrm{N}$ content (Figure 4A) and C:N ratio (Figure 4B) was unaffected by rootfeeding weevils or foliar-feeding aphids. Under $\mathrm{eCO}_{2}$ conditions, however, root-feeding weevils generally decreased $\mathrm{N}$ content (Figure 4A) and hence increased the aboveground C:N ratio (Figure 4B).

Crop cultivar affected the $\mathrm{C}$ content of above- and belowground tissues. Leaf $\mathrm{C}$ content was generally greater in cultivar Glen Clova (LS mean $=42.89 \pm 0.13$ ) than Gl. Ample (LS mean $\left.=42.36 \pm 0.13 ; F_{1,180}=15.83, p=0.0001\right)$. Root $\mathrm{C}$ content was similarly higher in Glen Clova (LS mean $=445.38 \pm 0.55$ ) than Glen Ample (LS mean $=44.33 \pm 0.55 ; F_{1,169}=24.62$, $p<0.0001)$. The interaction between the $\mathrm{CO}_{2}$ treatment and cultivar also affected crop biochemistry, with the greatest effects in aboveground tissues (Table 1). The C content of Glen Clova leaves was increased significantly by exposure to an $\mathrm{eCO}_{2}$ environment, whereas Glen Ample was largely unaffected (Table 1). While the impact on root $\mathrm{C}$ content was generally lower, there was a significant difference in the response of the cultivars to $\mathrm{eCO}_{2}$ with Glen Clova allocating more $\mathrm{C}$ to roots (Table 1). Similarly, leaf $\mathrm{N}$ content was lowered by $\mathrm{CO}_{2}$ treatment in both cultivars, but was most pronounced in the Glen Clova cultivar, while root $\mathrm{N}$ was largely unaffected by this

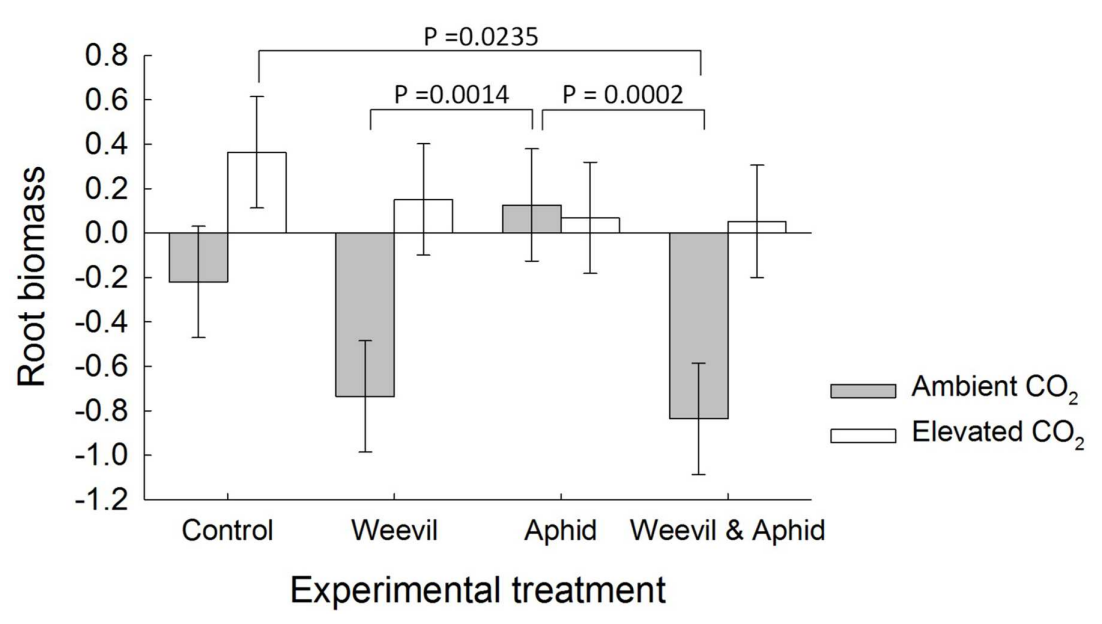

FIGURE 1 | The effect on raspberry root biomass of $\mathrm{CO}_{2}$ treatment (dark bars = ambient $390 \pm 50 \mu \mathrm{mol} / \mathrm{mol}$; light bars $=$ elevated $650 \pm 50 \mu \mathrm{mol} / \mathrm{mol}$ ) and herbivore treatments (herbivore-free control, root-feeding weevil only, foliar-feeding aphid only, both herbivores). Data are least square means \pm SE derived from final GLMM accounting for variation due to other treatments. Difference among treatments following Bonferroni adjustment for multiple comparisons indicated with solid lines $(p<0.05)$. 


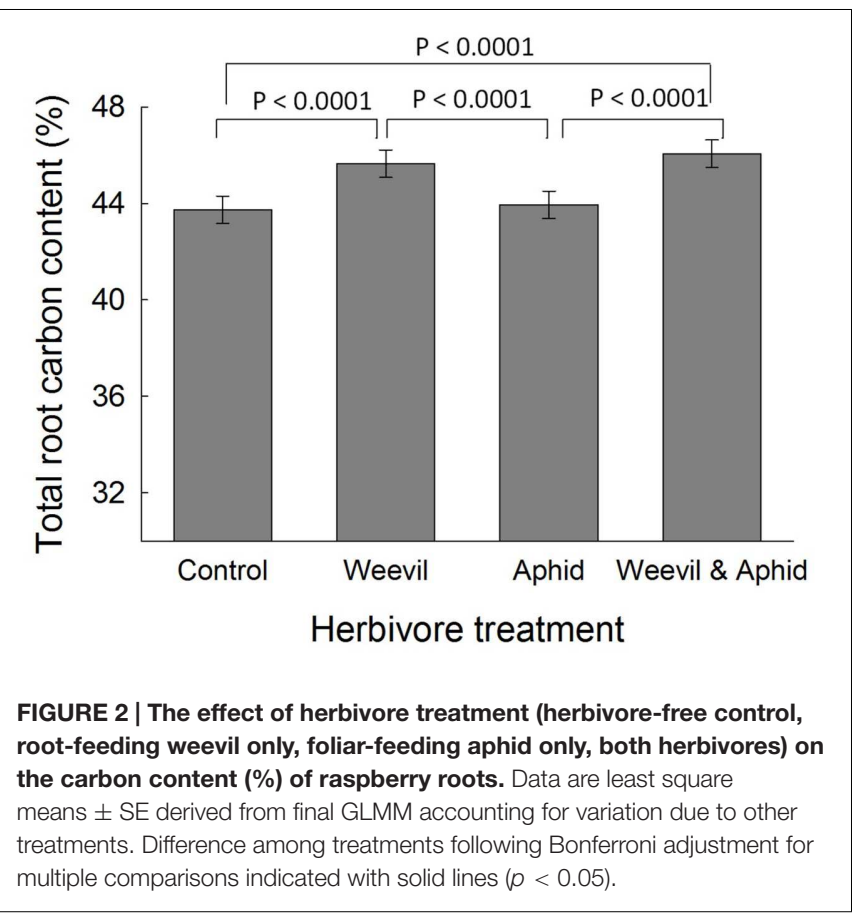

interaction (Table 1). These shifts in the crop biochemical balance translated into a highly significant increase in the aboveground $\mathrm{C}: \mathrm{N}$ ratio following exposure to an $\mathrm{eCO}_{2}$ environment, largely driven by the cultivar most resistant to herbivory (Glen Clova; Table 1).

\section{Insect Herbivore Responses}

Aphid abundance was weakly but positively related to leaf $\mathrm{C}$ content (Figure 5; $F_{1,77}=4.47, p=0.0378$ ). There was no statistically significant evidence that aphid abundance was related to either aboveground crop biomass $\left(F_{1,69}=2.77, p=0.0770\right)$, leaf $\mathrm{N}$ content $\left(F_{1,81}=3.44, p=0.0674\right)$ or the leaf $\mathrm{C}: \mathrm{N}$ ratio $\left(F_{1,74}=1.16, p=0.2860\right)$. Weevil abundance was positively related to root $C$ content (Figure 5; $F_{1,76}=5.56, p=0.0210$ ), but not $\operatorname{root} \mathrm{N}\left(F_{1,83}=0.41, p=0.5253\right)$ or belowground biomass $\left(F_{1,71}=1.80, p=0.1838\right)$ or the root $\mathrm{C}: \mathrm{N}$ ratio $\left(F_{1,80}=0.160\right.$, $p=6862$ ).

Despite bred resistance to aphid herbivory (cv. Glen Clova), there was no significant differences in insect herbivore abundance between the cultivars (aphid: $F_{1,69}=0.48, p=0.4894$; weevil: $\left.F_{1,68}=0.63 p=0.4311\right)$ nor was there any direct effect of the $\mathrm{CO}_{2}$ treatments on herbivore abundance (aphid: $F_{1,4}=3.58$, $p=0.4957$; weevil: $F_{1,4}=0.55, p=0.4996$ ).

There was no evidence that the abundance of each herbivore was influenced by the abundance of the other species (weevil: $F_{1,37}=3.01, p=0.0911$; aphid: $\left.F_{1,26}=2.44, p=0.1305\right)$, and hence no indication of a positive or negative plant-mediated herbivore interaction in this study.

\section{DISCUSSION}

Contrary to our first prediction, $\mathrm{eCO}_{2}$ did not directly increase crop biomass or the $\mathrm{C}: \mathrm{N}$ ratio of the plant tissues. Enhanced growth rates in response to $\mathrm{eCO}_{2}$ are common (Hentley et al., 2014; Dáder et al., 2016), especially in C3 plant species that at current $\mathrm{CO}_{2}$ concentrations operate below the maximum capacity of the carboxylating plant enzyme Rubisco (Ainsworth and Long, 2005; Leakey et al., 2009). These gains in biomass, however, range between 0 and $20 \%$ depending on plant species or functional type, for instance tree species typically accrue greater biomass than cereal crops or many wild herbaceous species (Ainsworth and Long, 2005; Ainsworth and Rogers, 2007; DeLucia et al., 2012). Furthermore, plant growth can even decrease in response to $\mathrm{eCO}_{2}$ according to the presence

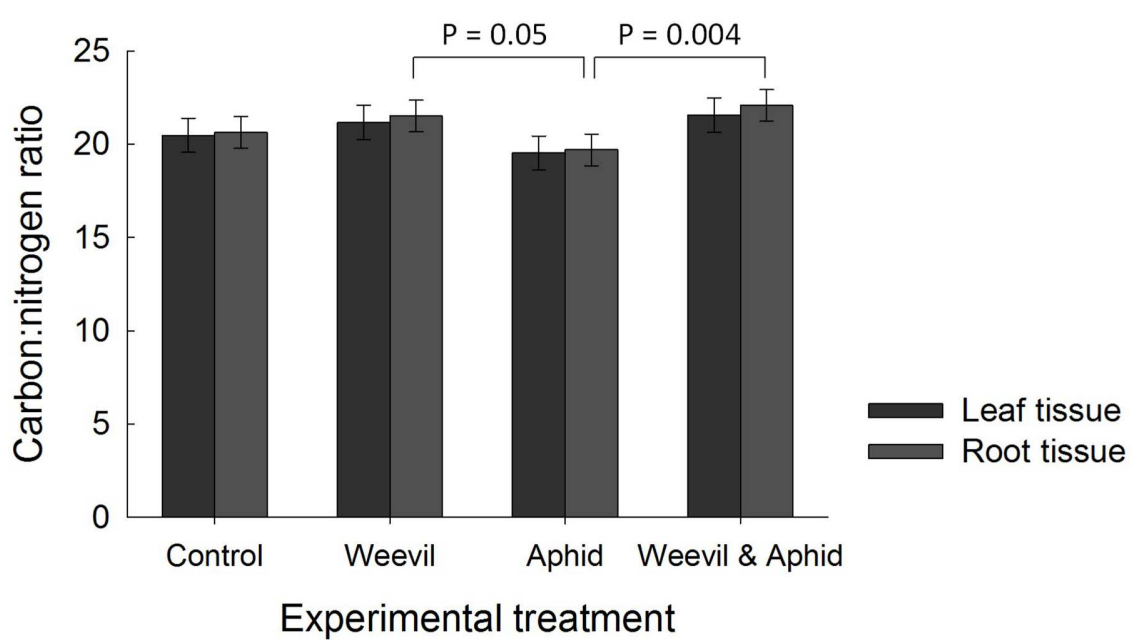

FIGURE 3 | The effect of herbivore treatment (herbivore-free control, root-feeding weevil only, foliar-feeding aphid only, both herbivores) on the ratio of carbon to nitrogen (C:N) in raspberry leaf (dark bars) and root (light bars) tissues. Data are least square means \pm SE derived from final GLMM accounting for variation due to other treatments. Difference among treatments following Bonferroni adjustment for multiple comparisons indicated with solid lines $(p<0.05)$. 
A

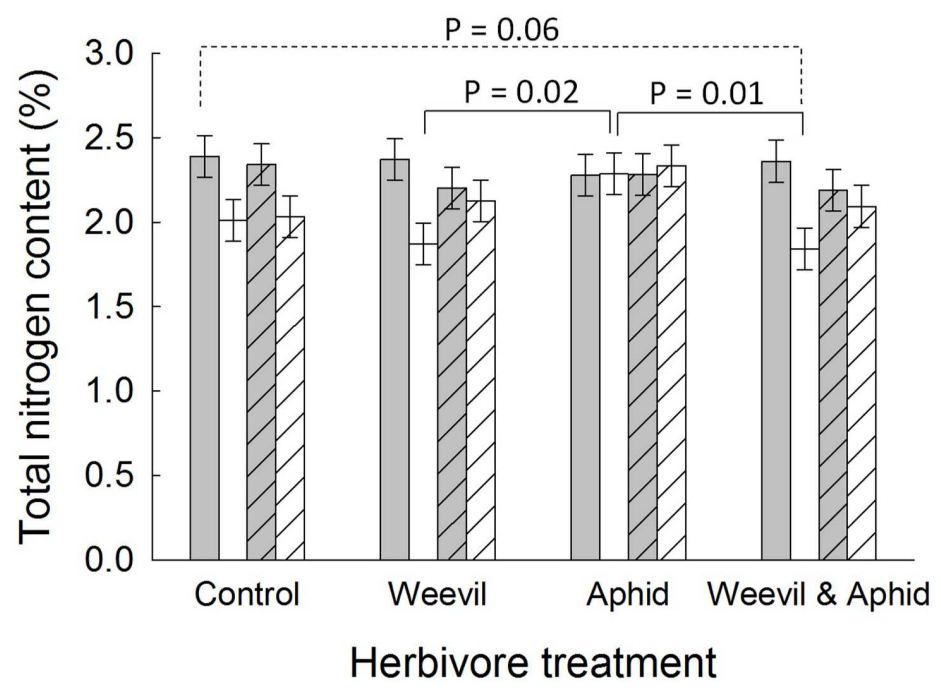

B

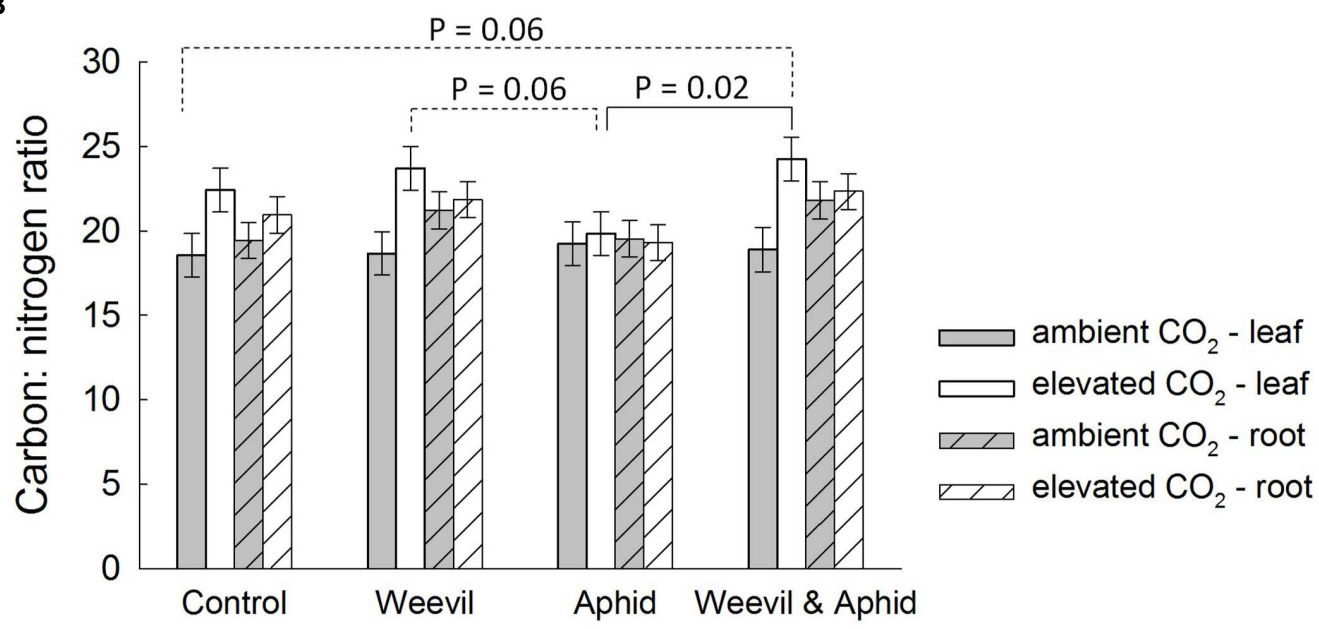

FIGURE 4 | The effect on raspberry $(\mathrm{A})$ carbon to nitrogen $(\mathrm{C}: \mathrm{N})$ ratio and $(\mathrm{B})$ nitrogen content $(\%)$ of the interaction between $\mathrm{CO}{ }_{2}(\mathrm{dark}$ bars = ambient $390 \pm 50 \mu \mathrm{mol} / \mathrm{mol}$; light bars = elevated $650 \pm 50 \mu \mathrm{mol} / \mathrm{mol}$ ) and herbivore treatments (herbivore-free control, root-feeding weevil only, foliar-feeding aphid only, both herbivores). Data are least square means \pm SE derived from final GLMM accounting for variation due to other treatments. Difference among treatments following Bonferroni adjustment for multiple comparisons indicated with dashed (marginally non-significant) or solid lines ( $0<0.05)$.

TABLE 1 | The effect on crop primary biochemistry of the interaction between crop cultivar and experimental $\mathrm{CO}_{2}$ treatment.

\begin{tabular}{|c|c|c|c|c|c|c|}
\hline \multirow{2}{*}{$\begin{array}{l}\text { Cultivar } \\
\mathrm{CO}_{2} \text { regime }\end{array}$} & \multicolumn{2}{|c|}{ Glen Clova } & \multicolumn{2}{|c|}{ Glen Ample } & \multirow[t]{2}{*}{$F(\mathrm{df})$} & \multirow[t]{2}{*}{$P$} \\
\hline & $390 \mu \mathrm{mol} / \mathrm{mol}$ & $650 \mu \mathrm{mol} / \mathrm{mol}$ & $390 \mu \mathrm{mol} / \mathrm{mol}$ & $650 \mu \mathrm{mol} / \mathrm{mol}$ & & \\
\hline \multicolumn{7}{|l|}{ Leaf } \\
\hline Nitrogen (\%) & $2.49 \pm 0.11$ & $1.96 \pm 0.11$ & $2.21 \pm 0.11$ & $2.04 \pm 0.11$ & $8.38(1,174)$ & 0.0043 \\
\hline Carbon (\%) & $42.34 \pm 0.19$ & $43.44 \pm 0.19$ & $42.20 \pm 0.19$ & $42.52 \pm 0.19$ & $8.55(1,180)$ & 0.0039 \\
\hline C:N & $17.75 \pm 1.13$ & $23.34 \pm 1.13$ & $19.91 \pm 1.13$ & $21.74 \pm 1.13$ & $8.90(1,169)$ & 0.0033 \\
\hline \multicolumn{7}{|l|}{ Root } \\
\hline Nitrogen (\%) & $2.34 \pm 0.11$ & $2.14 \pm 0.11$ & $2.17 \pm 0.11$ & $2.15 \pm 0.11$ & $3.78(1,173)$ & 0.0535 \\
\hline Carbon (\%) & $45.16 \pm 0.77$ & $45.59 \pm 0.77$ & $44.54 \pm 0.77$ & $44.11 \pm 0.77$ & $4.20(1,169)$ & 0.0420 \\
\hline C:N & $19.78 \pm 1.09$ & $21.96 \pm 1.09$ & $21.08 \pm 1.09$ & $21.11 \pm 1.09$ & $4.99(1,173)$ & 0.0268 \\
\hline
\end{tabular}

Data are least-square means and F \& $P$ values derived from final GLMM for each crop parameter. 
A

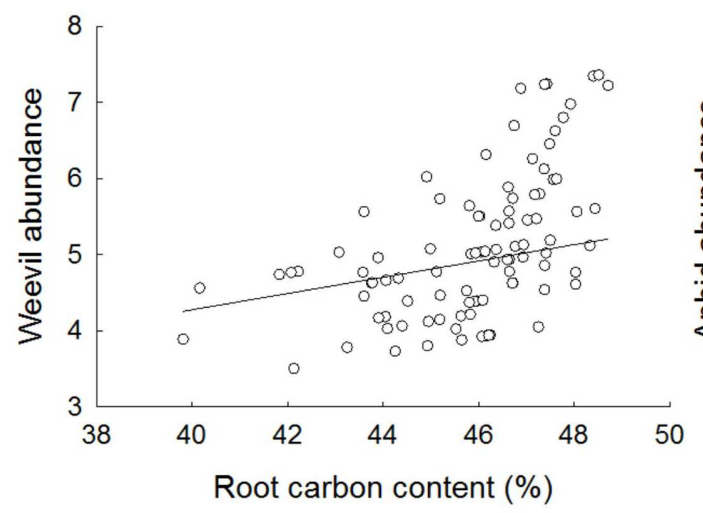

B

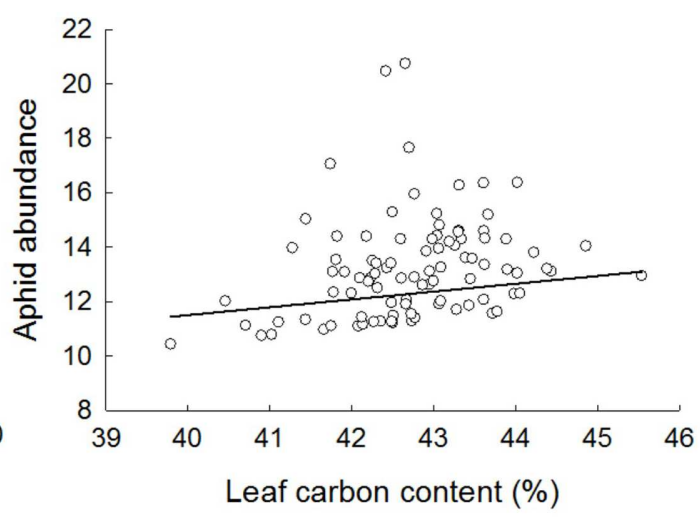

FIGURE 5 | The effect on the abundance of (A) weevils and (B) aphids of percent root and leaf carbon, respectively. Data are partial residual plots on the linear predictor scale and fitted lines are from final GLMM slopes accounting for variation due to other treatments and random effects.

of other environmental stressors, such as water availability (Bader et al., 2009; Kohler et al., 2009). Herbivores can also offset any plant biomass gain due to $\mathrm{eCO}_{2}$ by compensating for lower host-plant quality (e.g., reduced $\mathrm{N}$ content) by increasing or maintaining feeding rates through behavioral or physiological plasticity (Barbehenn et al., 2004; Johnson et al., 2011a).

Aphid and weevil abundance were independent of atmospheric $\mathrm{CO}_{2}$ concentrations, therefore there was also no evidence to support our second prediction that $\mathrm{eCO}_{2}$ would increase insect herbivore abundance. This finding fits among the many examples of aphids showing positive, negative or neutral responses to $\mathrm{CO}_{2}$ treatments (Bezemer et al., 1999; Newman et al., 2003; Sun and Ge, 2011; Dáder et al., 2016; Trębicki et al., 2016). Elsewhere, the nitrogen status (e.g., C:N ratio) of plant tissues has been shown to be intimately related to life-history or population performance of other aphid species under $\mathrm{eCO}_{2}$ (e.g., Myzus persicae Sulzer - Dáder et al., 2016; Rhopalosiphum padi L. - Trębicki et al., 2016). For instance, $\mathrm{eCO}_{2}$ decreased the foliar $\mathrm{N}$ content, but not the $\mathrm{C}$ content, in pepper plants (Capsicum annum L.) leading to longer individual development and lower fecundity of Myzus persicae due to an unfavorable nutritional quality of the host-plant (Dáder et al., 2016). In this experiment, the comparatively weak effects of $\mathrm{eCO}_{2}$ on the nitrogen balance in these raspberry cultivars offer a potential explanation for the lack of an effect on the aphid or weevil herbivore. Although unquantified here, this lack of a profound $\mathrm{eCO}_{2}$ effect on the $\mathrm{C}-\mathrm{N}$ balance implies it was unlikely to have modified the herbivore nutrients (e.g., essential amino acids) or the physical (e.g., cuticular waxes) or secondary (i.e., salicylic acid signaling pathway) defenses governing crop-herbivore interactions (Sun and Ge, 2011).

To understand better crop performance in $\mathrm{eCO}_{2}$ environments more work is clearly needed to unravel the interplay between, biochemical state, insect nutrition and performance in different crop varieties. In agreement with our study, Hentley et al. (2014) showed A. idaei did not respond to $\mathrm{eCO}_{2}$ when reared on these same raspberry cultivars (Glen Ample and Glen Clova) in the absence of the competing belowground herbivore. Similarly, Martin and Johnson (2011) also reported that $A$. idaei was unaffected by $\mathrm{eCO}_{2}$ on two other raspberry cultivars (Glen Rosa and Malling Jewel). However, aphid performance improved under $\mathrm{eCO}_{2}$ on other raspberry cultivars (Glen Lyon in Martin and Johnson, 2011; cv. Octavia - Hentley et al., 2014). These different outcomes among experiments and cultivars may point to the pre-dominance of the host-plant and insect identity over climate effects for herbivore performance, or just simply to experimental artifacts. Nonetheless, further experimental information on the role of different cultivars in shaping herbivory under climate change should continue to be an important avenue of research.

In terms of insect interactions, this experiment did not find evidence for the previously observed reciprocal feeding facilitation between these two spatially separated herbivores at $\mathrm{aCO}_{2}$ (McKenzie et al., 2013). Different crop growing conditions, use of different climate controlled facilities, and the fact that the current experiment was performed over a longer timeperiod (three 10-week runs over a calendar year vs. single run of 10 weeks) could explain this difference between these two studies.

Root herbivory affected root biomass and the C:N ratio of above- and belowground crop tissues and this was modified by the level of atmospheric $\mathrm{CO}_{2}$ that the crop experienced. In accord with our third prediction, root herbivory reduced belowground biomass significantly under $\mathrm{aCO}_{2}$ conditions, however, this impact dissipated under $\mathrm{eCO}_{2}$. This suggests a mitigation of herbivory on roots, potentially via impacts on herbivore performance at the individual or population level in an enriched $\mathrm{CO}_{2}$ atmosphere (Johnson et al., 2011a).

The most likely mechanism explaining the nullification of root herbivory is that increased concentrations of atmospheric carbon enable enhanced compensatory root re-growth, therefore 
lessening the net root loss. The net effect of the combination of root herbivory and $\mathrm{eCO}_{2}$ was similar to that found by Johnson and Riegler (2013), where the same combination produced root biomass at levels similar to those at $\mathrm{aCO}_{2}$ concentrations in the absence of herbivory. A notable difference is that Johnson and Riegler (2013) showed $\mathrm{eCO}_{2}$ to increase root biomass, which was subsequently reduced by herbivory; whereas here loss of biomass by root-herbivory under $\mathrm{aCO}_{2}$ conditions was mitigated by increased root production at $\mathrm{eCO}_{2}$. The net effect, however, remains the same with the abiotic and biotic pressures balancing one another.

Mirroring the change in crop biomass, the leaf C:N ratio was increased by root herbivory at $\mathrm{eCO}_{2}$, but not $\mathrm{aCO}_{2}$ conditions. This finding is consistent with our third prediction that root herbivores would cause changes in primary chemistry. We suggest that damage to roots from herbivory would restrict the uptake of nitrogen from the soil, as evidenced by the lower $\mathrm{N}$ concentrations in roots, and this likely shifted the C:N ratio in leaves (Zvereva and Kozlov, 2012). We found no support for induced resource sequestration (i.e., movement of $\mathrm{C}$ or $\mathrm{N}$ to the shoots) as a result of root herbivory, since foliar concentrations were not affected by either herbivore. On the contrary, we found evidence that root herbivores increased $\mathrm{C}$ concentrations in the roots. This may reflect 'feeding-induced resource accumulation' either because the herbivore is manipulating the plant for its own benefit, or the plant is mobilizing resources for root regrowth.

This study emphasizes the importance of understanding crop biomass and biochemical responses to climate change in the context of herbivory. In this system, biotic interactions appear as important as direct effects of climate change on crop productivity. Experimental work should continue to test how increasing the

\section{REFERENCES}

Ainsworth, E. A., and Long, S. P. (2005). What have we learned from 15 years of free-air $\mathrm{CO}_{2}$ enrichment (FACE)? A meta-analytic review of the responses of photosynthesis, canopy properties and plant production to rising $\mathrm{CO}_{2}$. New Phytol. 165, 351-372. doi: 10.1111/j.1469-8137.2004.01224.x

Ainsworth, E. A., and Rogers, A. (2007). The responses of photosynthesis and stomatal conductance to rising $\left[\mathrm{CO}_{2}\right]$ : mechanisms and environmental interactions. Plant Cell Environ. 30, 258-270. doi: 10.1111/j.1365-3040.2007.01641.x

Bader, M., Hiltbrunner, E., and Körner, C. (2009). Fine root responses of mature deciduous forest trees to free air carbon dioxide enrichment (FACE). Funct. Ecol. 23, 913-921. doi: 10.1111/j.1365-2435.2009.01574.x

Barbehenn, R., Karowe, D., and Chen, Z. (2004). Performance of a generalist grasshopper on a C3 and a C4 grass: compensation for the effects of elevated $\mathrm{CO}_{2}$ on plant nutritional quality. Oecologia $140,96-103$. doi: $10.1007 / \mathrm{s} 00442-$ 004-1555-x

Bezemer, T., Knight, K. J., Newington, J. E., and Jones, T. H. (1999). How general are aphid responses to elevated atmospheric $\mathrm{CO}_{2}$ ? Ann. Entomol. Soc. Am. 92, 724-730. doi: 10.1093/aesa/92.5.724

Blackshaw, R., and Kerry, B. (2008). Root Herbivory in Agricultural Ecosystems. Root Feeders: An Ecosystem Perspective. Wallingford: CAB International, 35-53.

Blossey, B., and Hunt-Joshi, T. R. (2003). Belowground herbivory by insects: influence on plants and aboveground herbivores. Annu. Rev. Entomol. 48, 521-547. doi: 10.1146/annurev.ento.48.091801.112700

Climate Change (2007). "Climate change 2007: the physical science basis," in Contribution of Working Group I to the Fourth Assessment Report of trophic complexity of the crop system affects species interactions and crop performance in a carbon-enriched world (Soler et al., 2012; Hentley et al., 2014; Dáder et al., 2016; Trębicki et al., 2016).

\section{AUTHOR CONTRIBUTIONS}

SM helped design and run the experiment, carried out measurements and contributed to analysis and paper preparation. THJ and $\mathrm{RH}$ helped conceive and design the experiment and contributed to the writing of the paper. AV helped conceive, design the experiment, analyzed the data, and prepared the paper. SJ helped conceive and design the experiment and prepared the paper. NO conceived and oversaw biochemical analysis of the experiment and contributed to the writing of the paper.

\section{FUNDING}

A Natural Environment Research Council (NERC) Ph.D. Studentship (NEC04280) with CASE support from the James Hutton Institute (JHI) supported SM. The NERC CEH National Capability Project on plant-soil interactions (NEC04623) supported the analysis of plant chemistry.

\section{ACKNOWLEDGMENT}

Thanks to Dr. Adam Butler at Biomathematics and Statistics Scotland for advice on statistical modeling.

the Intergovernmental Panel on Climate Change, eds S. Solomon, D. Qin, M. Manning, Z. Chen, M. Marquis, K. B. Averyt, et al. (Cambridge: Cambridge University Press), 996.

Crawley, M. J. (1989). Insect herbivores and plant population dynamics. Annu. Rev. Entomol. 34, 531-562. doi: 10.1146/annurev.en.34.010189.002531

Dáder, B., Fereres, A., Moreno, A., and Trębicki, P. (2016). Elevated $\mathrm{CO}_{2}$ impacts bell pepper growth with consequences to Myzus persicae life history, feeding behaviour and virus transmission ability. Sci. Rep. 6, 19120. doi: $10.1038 /$ srep 19120

DeLucia, E. H., Nabity, P. D., Zavala, J. A., and Berenbaum, M. R. (2012). Climate change: resetting plant-insect interactions. Plant Physiol. 160, 1677-1685. doi: 10.1104/pp.112.204750

Elston, D. A., Moss, R., Boulinier, T., Arrowsmith, C., and Lambin, X. (2001). Analysis of aggregation, a worked example: numbers of ticks on red grouse chicks. Parasitology 122, 563-569. doi: 10.1017/S0031182001007740

Erb, M., Huber, M., Robert, C. A., Ferrieri, A. P., Machado, R. A., and Arce, C. C. (2013). The role of plant primary and secondary metabolites in rootherbivore behaviour, nutrition and physiology. Adv. Insect Physiol. 45, 53-95. doi: 10.1016/B978-0-12-417165-7.00002-7

Hagenbucher, S., Wäckers, F. L., and Romeis, J. (2014). Indirect multi-trophic interactions mediated by induced plant resistance: impact of caterpillar feeding on aphid parasitoids. Biol. Lett. 10, 20130795. doi: 10.1098/rsbl. 2013.0795

Hentley, W. T., Hails, R. S., Johnson, S. N., Jones, T. H., and Vanbergen, A. J. (2014). Top-down control by Harmonia axyridis mitigates the impact of elevated atmospheric $\mathrm{CO}_{2}$ on a plant-aphid interaction. Agric. For. Entomol. 16, 350-358. doi: 10.1111/afe. 12065 
Huang, J., Liu, M., Chen, F., Griffiths, B. S., Chen, X., Johnson, S. N., et al. (2012). Crop resistance traits modify the effects of an aboveground herbivore, brown planthopper, on soil microbial biomass and nematode community via changes to plant performance. Soil Biol. Biochem. 49, 157-166. doi: 10.1016/j.soilbio.2012.02.022

Huang, W., Siemann, E., Yang, X., Wheeler, G. S., and Ding, J. (2013). Facilitation and inhibition: changes in plant nitrogen and secondary metabolites mediate interactions between above-ground and below-ground herbivores. Proc. R. Soc. B Biol. Sci. 280, 20131318. doi: 10.1098/rspb.2013.1318

IPCC (2013). "Summary for policymakers," in Climate Change 2013: The Physical Science Basis. Contribution of Working Group I to the Fifth Assessment Report of the Intergovernmental Panel on Climate Change, eds D. Q. T. F. Stocker, G.K. Plattner, M. Tignor, S. K. Allen, J. Boschung, A. Nauels, et al. (Cambridge: Cambridge University Press).

Johnson, S. N., Barton, A. T., Clark, K. E., Gregory, P. J., McMenemy, L. S., and Hancock, R. D. (2011a). Elevated atmospheric carbon dioxide impairs the performance of root-feeding vine weevils by modifying root growth and secondary metabolites. Glob. Change Biol. 17, 688-695. doi: 10.1111/j.13652486.2010.02264.x

Johnson, S. N., Erb, M., and Hartley, S. E. (2016a). Roots under attack: contrasting plant responses to below- and aboveground insect herbivory. New Phytol. 210, 413-418. doi: 10.1111/nph.13807

Johnson, S. N., Hawes, C., and Karley, A. J. (2009). Reappraising the role of plant nutrients as mediators of interactions between root- and foliarfeeding insects. Funct. Ecol. 23, 699-706. doi: 10.1111/j.1365-2435.2009. 01550.x

Johnson, S. N., Mitchell, C., McNicol, J. W., Thompson, J., and Karley, A. J. (2013). Downstairs drivers - root herbivores shape communities of aboveground herbivores and natural enemies via changes in plant nutrients. J. Anim. Ecol. 82, 1021-1030. doi: 10.1111/1365-2656.12070

Johnson, S. N., and Riegler, M. (2013). Root damage by insects reverses the effects of elevated atmospheric $\mathrm{CO}_{2}$ on eucalypt seedlings. PLoS ONE 8:e79479. doi: 10.1371/journal.pone.0079479

Johnson, S. N., Ryalls, J. M. W., and Staley, J. T. (2016b). "Impacts of climate and atmospheric change on aboveground-belowground invertebrate interactions," in Global Climate Change and Terrestrial Invertebrates, eds S. N. Johnson and T. H. Jones (Oxford: Wiley).

Johnson, S. N., Staley, J. T., McLeod, F. A. L., and Hartley, S. E. (2011b). Plant-mediated effects of soil invertebrates and summer drought on aboveground multitrophic interactions. J. Ecol. 99, 57-65. doi: 10.1111/j.13652745.2010.01748.x

Kaplan, I., Halitschke, R., Kessler, A., Rehill, B. J., Sardanelli, S., and Denno, R. F. (2008). Physiological integration of roots and shoots in plant defense strategies links above- and belowground herbivory. Ecol. Lett. 11, 841-851. doi: 10.1111/j.1461-0248.2008.01200.x

Kohler, J., Caravaca, F., del Mar Alguacil, M., and Roldán, A. (2009). Elevated CO 2 increases the effect of an arbuscular mycorrhizal fungus and a plant-growth-promoting rhizobacterium on structural stability of a semiarid agricultural soil under drought conditions. Soil Biol. Biochem. 41, 1710-1716. doi: 10.1016/j.soilbio.2009.05.014

Leakey, A. D. B., Ainsworth, E. A., Bernacchi, C. J., Rogers, A., Long, S. P., and Ort, D. R. (2009). Elevated $\mathrm{CO}_{2}$ effects on plant carbon, nitrogen, and water relations: six important lessons from FACE. J. Exp. Bot. 60, 2859-2876. doi: 10.1093/jxb/erp096

Littell, R. C., Milliken, G. A., Stroup, W. W., and Wolfinger, R. D. (1996). SAS System for Mixed Models. Cary, NC: SAS Institute Inc.

Luo, Y., Hui, D., and Zhang, D. (2006). Elevated $\mathrm{CO}_{2}$ stimulates net accumulations of carbon and nitrogen in land ecosystems: a meta-analysis. Ecology 87, 53-63. doi: 10.1890/04-1724

Martin, P., and Johnson, S. N. (2011). Evidence that elevated $\mathrm{CO}_{2}$ reduces resistance to the European large raspberry aphid in some raspberry cultivars. J. Appl. Entomol. 135, 237-240. doi: 10.1111/j.1439-0418.2010. 01544.x

McKenzie, S. W., Vanbergen, A. J., Hails, R. S., Jones, T. H., and Johnson, S. N. (2013). Reciprocal feeding facilitation between above- and below-ground herbivores. Biol. Lett. 9, 20130341. doi: 10.1098/rsbl.2013.0341

McMenemy, L. S., Mitchell, C., and Johnson, S. N. (2009). Biology of the European large raspberry aphid (Amphorophora idaei): its role in virus transmission and resistance breakdown in red raspberry. Agric. For. Entomol. 11, 61-71. doi: 10.1111/j.1461-9563.2008.00409.x

Megías, A. G., and Müller, C. (2010). Root herbivores and detritivores shape aboveground multitrophic assemblage through plant-mediated effects. J. Anim. Ecol. 79, 923-931. doi: 10.1111/j.1365-2656.2010.01681.x

Moorhouse, E. R., Charnley, A. K., and Gillespie, A. T. (1992). A review of the biology and control of the vine weevil, Otiorhynchus sulcatus (Coleoptera: Curculionidae). Ann. Appl. Biol. 121, 431-454. doi: 10.1111/j.17447348.1992.tb03455.x

Newingham, B., Callaway, R., and BassiriRad, H. (2007). Allocating nitrogen away from a herbivore: a novel compensatory response to root herbivory. Oecologia 153, 913-920. doi: 10.1007/s00442-007-0791-2

Newman, J. A., Gibson, D. J., Parsons, A. J., and Thornley, J. H. M. (2003). How predictable are aphid population responses to elevated $\mathrm{CO}_{2}$ ? J. Anim. Ecol. 72, 556-566. doi: 10.1046/j.1365-2656.2003.00725.x

Orians, C. M., Thorn, A., and Gómez, S. (2011). Herbivore-induced resource sequestration in plants: why bother? Oecologia 167, 1-9. doi: 10.1007/s00442011-1968-2

Pierre, P. S., Dugravot, S., Cortesero, A.-M., Poinsot, D., Raaijmakers, C. E., Hassan, H. M., et al. (2012). Broccoli and turnip plants display contrasting responses to belowground induction by Delia radicum infestation and phytohormone applications. Phytochemistry 73, 42-50. doi: 10.1016/j.phytochem.2011. 09.009

Robert, C. A. M., Ferrieri, R. A., Schirmer, S., Babst, B. A., Schueller, M. J., Machado, R. A. R., et al. (2014). Induced carbon reallocation and compensatory growth as root herbivore tolerance mechanisms. Plant Cell Environ. 37, 2613-2622. doi: 10.1111/pce.12359

Robinson, E. A., Ryan, G. D., and Newman, J. A. (2012). A meta-analytical review of the effects of elevated $\mathrm{CO}_{2}$ on plant-arthropod interactions highlights the importance of interacting environmental and biological variables. New Phytol. 194, 321-336. doi: 10.1111/j.1469-8137.2012.04 074.x

Ryalls, J., and Harrington, R. (2016). "Climate and atmospheric change impacts on aphids as vectors of plant diseases," in Global Climate Change and Terrestrial Invertebrates, eds S. N. Johnson and T. H. Jones (Oxford: Wiley).

Ryalls, J. M. W., Riegler, M., Moore, B. D., Lopaticki, G., and Johnson, S. N. (2013). Effects of elevated temperature and $\mathrm{CO}_{2}$ on abovegroundbelowground systems: a case study with plants, their mutualistic bacteria and root / shoot herbivores. Front. Plant Sci. 4:445. doi: 10.3389/fpls.2013. 00445

Schultz, J. C., Appel, H. M., Ferrieri, A. P., and Arnold, T. M. (2013). Flexible resource allocation during plant defense responses. Front. Plant Sci. 4:324. doi: 10.3389/fpls.2013.00324

Soler, R., Putten, W., Harvey, J., Vet, L. M., Dicke, M., and Bezemer, T. M. (2012). Root herbivore effects on aboveground multitrophic interactions: patterns, processes and mechanisms. J. Chem. Ecol. 38, 755-767. doi: 10.1007/s10886012-0104-z

Son, Y., and Lewis, E. E. (2005). Modelling temperature-dependent development and survival of Otiorhynchus sulcatus (Coleoptera: Curculionidae). Agric. For. Entomol. 7, 201-209. doi: 10.1111/j.1461-9555.2005.00260.x

Staley, J. T., and Johnson, S. N. (2008). "Climate change impacts on root herbivores," in Root Feeders: An Ecosystem Perspective, eds S. N. Johnson and P. J. Murray (Wallingford: CABI), 192-215.

Stevnbak, K., Scherber, C., Gladbach, D. J., Beier, C., Mikkelsen, T. N., and Christensen, S. (2012). Interactions between above- and belowground organisms modified in climate change experiments. Nat. Clim. Chang. 2, 805808. doi: $10.1038 /$ nclimate 1544

Strauss, S. Y., and Agrawal, A. A. (1999). The ecology and evolution of plant tolerance to herbivory. Trends Ecol. Evol. 14, 179-185. doi: 10.1016/S01695347(98)01576-6

Sun, Y., and Ge, F. (2011). How do aphids respond to elevated $\mathrm{CO}_{2}$ ? J. Asia-Pac. Entomol. 14, 217-220. doi: 10.1016/j.aspen.2010.08.001

Tao, L., and Hunter, M. D. (2013). Allocation of resources away from sites of herbivory under simultaneous attack by aboveground and belowground herbivores in the common milkweed, Asclepias syriaca. Arthropod Plant Interact. 7, 217-224. doi: 10.1007/s11829-012-9235-y

Trębicki, P., Vandegeer, R. K., Bosque-Pérez, N. A., Powell, K. S., Dader, B., Freeman, A. J., et al. (2016). Virus infection mediates the effects of 
elevated $\mathrm{CO}_{2}$ on plants and vectors. Sci. Rep. 6, 22785. doi: 10.1038/srep 22785

Villani, M. G., and Wright, R. J. (1990). Environmental influences on soil macroarthropod behavior in agricultural systems. Annu. Rev. Entomol. 35, 249-269. doi: 10.1146/annurev.en.35.010190.001341

Watts, S. M., Dodson, C. D., and Reichman, O. J. (2011). The roots of defense: plant resistance and tolerance to belowground herbivory. PLOS ONE 6:e18463. doi: 10.1371/journal.pone.0018463

Zvereva, E., and Kozlov, M. (2012). Sources of variation in plant responses to belowground insect herbivory: a meta-analysis. Oecologia 169, 441-452. doi: 10.1007/s00442-011-2210-y
Conflict of Interest Statement: The authors declare that the research was conducted in the absence of any commercial or financial relationships that could be construed as a potential conflict of interest.

Copyright (c) 2016 McKenzie, Johnson, Jones, Ostle, Hails and Vanbergen. This is an open-access article distributed under the terms of the Creative Commons Attribution License (CC BY). The use, distribution or reproduction in other forums is permitted, provided the original author(s) or licensor are credited and that the original publication in this journal is cited, in accordance with accepted academic practice. No use, distribution or reproduction is permitted which does not comply with these terms. 